\title{
PEMBUATAN BRIKET DARI KULIT BUAH MAHONI DENGAN VARIASI JENIS DAN KONSENTRASI PEREKAT
}

\section{Synthesis Of Briquettes From Mahogany Rind With Variation In Type And Concentration of Adhesives}

\author{
Budhi Indrawijaya $^{1 *}$, Arif Budiawan ${ }^{1}$, Jean Gegana ${ }^{1}$ \\ ${ }^{1}$ Program Studi Teknik Kimia, Fakultas Teknik, Universitas Pamulang, \\ Jl. Witana Harja No. 18b, Tangerang Selatan, 15417 \\ *Untuk Korespondensi, email : budhi.indrawijaya@gmail.com
}

Received : 23 Juni 2020; Accepted : 14 Juli 2020; Publish : Juli 2020

\begin{abstract}
ABSTRAK
Kulit buah mahoni merupakan bagian pada tanaman mahoni yang tidak dimanfaatkan, dengan demikian pemanfaatannya untuk membuat briket adalah solusi dijadikan bahan bakar. Penelitian ini bertujuan untuk mengetahui apakah kulit buah mahoni bisa diarangkan serta menentukan konsentrasi dan jenis perekat yang tepat agar briket yang dihasilkan berkualitas paling baik sesuai dengan SNI 016235-2000. Biomassanya diperoleh dari desa tirtosworo, Wonogiri. Penelitian ini menggunakan metode eskperimen di laboratorium dengan beberapa tahap, yaitu (1) penjemuran biomassa; (2) pirolisis; (3) Perekatan; (4) Pembentukan; (5) Analisa kualitas briket. Variabel penelitian meliputi jenis perekat yaitu tepung tapioka dan tepung jagung serta konsentrasi tepung pada perekat yaitu $10 \%$, $15 \%, 20 \%$ serta $25 \%$ dari total lem yang dihasilkan, dengan perbandingan arang dan lem 2:3. Hasil penelitian diperoleh bahwa kulit buah mahoni bisa diarangkan sehingga bisa dijadikan bahan utama briket dengan jenis perekat yaitu tepung tapioka 25\% yang karakteristik briketnya : (a) kadar air 2,7731\%; (b) kadar abu 7,4227\%; (c) kadar zat menguap 14,2192\%; dan (d) kadar karbon terikat $75,5850 \%$.
\end{abstract}

Kata Kunci : Briket, kulit buah mahoni, tepung tapioka, tepung jagung

\section{ABSTRACT}

Mahogany rind is a part of mahogany plant that are not used, so its use to make briquettes is a solution used as fuel. This research discusses the mahogany skin that can be fabricated and determined according to the type used so that the briquettes produced are of the highest quality in accordance with SNI 01-6235-2000. The biomass were obtained from the village of Tirtosworo, Wonogiri. This study uses an experimental method in a laboratory with several works, namely (1) biomass drying; (2) pyrolysis; (3) Gluing; (4) Establishment; (5) Analysis of briquette quality. The research variable was published by the type of adhesive, tapioca flour and corn flour and the concentration of flour in the adhesive, namely 10\%, 15\%, 20\% and 25\% of the total glue produced, using charcoal and 2: 3 glue. The results of the study were obtained from fruit skin mahogany can be made up so that the main ingredients of briquettes can be made with the type of adhesive that is 25\% tapioca flour which is typical of briquettes: (a) Water content is $2.7731 \%$; (b) ash content is 7,4227\%; (c) volatile matter content is $14,2192 \%$; and $(d)$ bound carbon content $75.5850 \%$.

Keyword : Briquette, Mahogany rind, Tapioca adhesive, Cornstarch adhesive 


\section{PENDAHULUAN}

Dewasa ini, ketersediaan minyak bumi kian menipis karena semakin hari semakin banyak penggunaan minyak bumi untuk berbagai kebutuhan. Energi biomassa dapat menjadi solusi untuk mengatasi hal tersebut. Energi biomassa merupakan sumber energi alternatif terbarukan yang berasal dari hasil buangan atau limbah tumbuh-tumbuhan ataupun bahan organik yang ketersediaannya melimpah serta mudah ditemukan. Limbah tumbuh-tumbuhan dan bahan organik antara lain limbah kayu, tempurung kelapa, sekam padi, ampas tebu dan tongkol jagung merupakan bahan-bahan organik yang biasanya tidak digunakan sehingga menjadi sampah organik, padahal bahan-bahan tesebut masih memiliki nilai ekonomis apabila diolah menjadi hal lain.

Salah satu pemanfaatan dari bahan-bahan tersebut adalah sebagai bahan baku untuk pembuatan briket arang. Briket arang adalah bahan bakar padat yang mengandung karbon, memiliki nilai kalori yang tinggi, dan dapat menyala dalam waktu yang lama. Bioarang adalah arang yang diperoleh dengan membakar biomassa kering tanpa udara (pirolisis). Sedangkan biomassa adalah bahan organik yang berasal dari jasad hidup. Biomassa sebenarnya dapat digunakan secara langsung sebagai sumber energi panas untuk bahan bakar, tetapi kurang efisien. Nilai bakar biomassa hanya sekitar $3000 \mathrm{kal}$, sedangkan bioarang mampu menghasilkan 5000 kal (Seran, 1990) ${ }^{[8]}$. Panas yang dihasilkan oleh briket bioarang relatif lebih tinggi dibandingkan dengan kayu biasa dan nilai kalor dapat mencapai 5.000 kalori (Soeyanto, 1982) [11]. Nilai kalor briket sangat berpengaruh pada efisiensi pembakaran briket. Makin tinggi nilai kalori briket makin bagus kualitas briket tersebut karena efisiensi pembakarannya tinggi (Indrawijaya, B, 2019) [2]. Faktor-faktor yang mempengaruhi sifat briket arang adalah berat jenis bahan bakar atau berat jenis serbuk arang, kehalusan serbuk, suhu karbonisasi, dan tekanan pada saat dilakukan pencetakan. Selain itu, pencampuran formula dengan briket juga mempengaruhi sifat briket. Syarat briket yang baik adalah briket yang permukaannya halus dan tidak meninggalkan bekas hitam ditangan (Sinurat, 2011) ${ }^{[9]}$. Briket yang baik adalah briket yang kualitasnya sudah distandarisasi oleh Badan Standarisasi Nasional bahwa briket yang memenuhi standar sebagai bahan bakar dapat dilihat dari kadar air, kadar abu, kadar zat menguap serta nilai kalor (Sudiro dan Sigit S, 2014) ${ }^{[12]}$.

Bahan baku yang bisa menjadi bahan baku pembuatan briket salah satunya adalah limbah kulit buah mahoni. Mahoni berdaun kecil lebih baik kualitas kayunya dibandingkan mahoni berdaun lebar (Kementrian Kehutanan, 2011) ${ }^{[4]}$. Mahoni termasuk tanaman kayu yang mudah dibudidayakan karena dapat tumbuh pada berbagai tempat dan berbagai jenis tanah. Umumnya dapat tumbuh pada tanah yang kondisinya agak liat dengan ketinggian sekitar 1000 mdpl. Telah banyak penelitian yang dilakukan mengenai tanaman ini, dimana dihasilkan keragaman genetik mahoni yang cukup tinggi (Iswanto, 2016) ${ }^{[3]}$.

$$
\text { Limbah tersebut masih jarang }
$$
dimanfaatkan untuk meningkatkan nilai ekonomisnya dengan membuatnya menjadi briket melainkan hanya terbuang begitu saja karena bagian buah mahoni yang sering dimanfaatkan adalah bagian biji buahnya saja. Bagian ini berwarna putih dan rasanya pahit dan dimanfaatkan sebagai obat tradisional untuk mengobati nyeri haid, sembelit hingga hipertensi. Biji digunakan sebagai obat untuk malaria, kencing manis, tekanan darah tinggi, rematik, kurang nafsu makan, masuk angin, demam serta ekzema (Samsi, 2000) ${ }^{[7]}$. Selain menjadi briket, salah satu upaya peningkatan nilai ekonomis pohon mahoni terutama kulit buahnya yaitu dapat dilakukan dengan mengolahnya menjadi karbon aktif (Salamah, 2008) ${ }^{[6]}$.

Dalam pembuatan briket bahan lain yang diperlukan adalah perekat alami, biasanya adalah campuran air dan tepung. Perekat ini berfungsi agar partikel arang kulit mahoni berikatan sehingga tidak mudah hancur saat digunakan. Penggunaan perekat berbahan dasar tepung tapioka daan tepung jagung ini ini memiliki beberapa keuntungan yaitu harganya murah dan sangat mudah dijumpai di pasar. Dengan adanya bahan perekat maka susunan partikel makin baik, teratur dan lebih padat sehingga dalam proses pengempaan keteguhan tekanan arang briket akan semakin baik. Dalam penggunaan bahan perekat harus memperhatikan faktor ekonomi maupun non- 
ekonominya (Noldi, 2009) ${ }^{[5]}$. Dalam penelitian ini digunakan beberapa variasi percobaan yaitu pada perbedaan konsentrasi perekat yang ditambahkan sebanyak 4 variasi dan jenis perekatnya sebanyak 2 variasi. Parameter pengujian briket ini antara lain kadar air, kadar abu, dan kadar zat menguap sesuai dengan SNI 01-6235-2000 (Badan Standarisasi Nasional, 2000) ${ }^{[1]}$.

\section{METODOLOGI PENELITIAN}

Metode yang dilakukan dalam penelitian ini adalah metode eksperimen yang dilaksanakan di laboratorium. Bahan-bahan yang digunakan dalam penelitian ini adalah:

1. Kulit buah mahoni kering yang diambil disekitaran kebun mahoni di Desa Tirtosworo, Kecamatan Wonogiri, Kabupaten Wonogiri.

2. Air yang digunakan untuk bahan perekat adalah air keran.

3. Tepung yang digunakan untuk bahan perekat antara lain tepung tapioka dan tepung jagung (SNI $3451: 2011)^{[10]}$ yang diperoleh dari Pasar Modern Malabar, Kota Tangerang.

Pengumpulan data dilakukan dengan melakukan eksperimen atau praktikum di Laboratorium. Alat yang digunakan antara lain : oven, pisau, kaleng, ayakan, cetakan, gelas ukur, sendok, timbangan, pengaduk, blender, hot plate, desikator, tang krus, tanur, cawan oven, dan cawan tanur. Prosedur kerja yang dilakukan yaitu dengan modifikasi jenis dan konsentrasi perekat untuk mengetahui pengaruh variasi jenis dan konsentrasi perekat terhadap briket yang dihasilkan.

Prosedur kerja meliputi persiapan bahan, karbonasi, penghancuran dan pengayakan arang, Kulit buah mahoni pertama-tama dikeringkan, lalu diarangkan dengan cara pembakaran tidak langsung tanpa udara, dihaluskan menjadi serbuk lalu ditambah dengan perekat berbahan dasar tepung tapioka dan tepung jagung dengan konsentrasi tepung untuk membuat lem sebanyak 10\%, 15\%, 20\%, dan $25 \%$. Pencampuran perekat dengan arang dengan komposisi yang sudah ditentukan yaitu perbandingan antara arang (14 gram) dan perekat (21 gram) adalah 2:3. Pembuatan lem/perekat yaitu dengan menimbang tepung dan air dengan jumlah tertentu, lalu dipanaskan diatas kompor dan diaduk hingga mengental. Pencampuran dan pencetakan dilakukan secara manual, hingga membentuk briket dengan ukuran seperti silinder dengan berat masingmasing briket adalah 35 gram. Briket yang sudah dibentuk dipanaskan dalam oven pada suhu $100{ }^{\circ} \mathrm{C}$ selama 9 jam. Briket yang sudah kering selanjutnya di analisa kualitasnya yang parameter pengujiannya meliputi kadar air, kadar abu, kadar zat menguap dan kadar karbon terikat.

\section{Kadar Air}

Untuk menentukan kadar air pada briket, ditimbang sampel sebanyak kurang lebih 5 gram ke dalam cawan oven, lalu dimasukkan ke dala oven pada suhu $105-110{ }^{\circ} \mathrm{C}$ selama 3 jam. Dikeluarkan dan didinginkan di dalam desikator dan ditimbang. Kadar air dihitung dengan menggunakan persamaan :

$$
\text { Kadar Air }(\%)=\frac{B-C}{B-A} \times 100 \%
$$

Keterangan :

A = Bobot cawan kosong (gram)

$\mathrm{B}=$ Bobot cawan + sampel sebelum pemanasan (gram)

$\mathrm{C}=$ Bobot cawan + sampel setelah pemanasan (gram)

2. Kadar abu

Untuk menentukan kadar abu pada briket, ditimbang sampel sebanyak kurang lebih 2 gram ke dalam cawan tanur, lalu dimasukkan ke dalam oven pada suhu $600{ }^{\circ} \mathrm{C}$ selama 1 jam. Dikeluarkan dan didinginkan di dalam desikator dan ditimbang. Kadar air dihitung dengan menggunakan persamaan :

$$
\text { Kadar Abu }(\%)=\frac{C}{B} \times 100 \%
$$


Keterangan :

$\mathrm{B}=$ Bobot sampel sebelum pemanasan (gram)

$\mathrm{C}=$ Bobot cawan + sampel setelah pemanasan (gram)

\section{Kadar zat menguap}

Untuk menentukan kadar zat menguap, ditimbang sampel sisa cek kadar air ke dalam cawan tanur, lalu dimasukkan ke dalam tanur pada suhu $900{ }^{\circ} \mathrm{C}$ selama 7 menit. Dikeluarkan dan didinginkan di dalam desikator dan ditimbang. Kadar zat menguap dihitung dengan menggunakan persamaan :

$$
\operatorname{KZM}(\%)=\frac{B-C}{W} \times 100 \%
$$

Keterangan :

$\mathrm{B}=$ Bobot sampel sisa setelah cek kadar air (gram)

$\mathrm{C}=$ Bobot sampel setelah pemanasan $900^{\circ} \mathrm{C}$ (gram)

$\mathrm{W}=$ Bobot sampel awal saat cek kadar air (gram)

4. Kadar Karbon Terikat (KKT)

Untuk menentukan kadar karbon terikat bisa dihitung dengan persamaan:

$K K T(\%)=100 \%-(M+V+A) \%$

Keterangan :

$\mathrm{M}=$ Kadar air $(\%)$

$\mathrm{V}=$ Kadar zat menguap (\%)

$\mathrm{A}=\mathrm{Kadar}$ abu $(\%)$

\section{HASIL DAN PEMBAHASAN}

\section{A. Pembuatan Briket Arang}

Briket yang dihasilkan memiliki bentuk silinder dan cukup keras dengan variasi jenis tepung perekat yaitu tepung tapioka dan tepung jagung yang masing-masing konsentrasinya bervariasi yaitu 10\%, 15\%, $20 \%$, dan $20 \%$ seperti yang pada Tabel 1 .
Tabel 1. Kode Sampel Briket

\begin{tabular}{ccc}
\hline No & Variasi & Kode \\
\hline $\mathbf{1}$ & Briket perekat tapioka 10\% & T1 \\
\hline $\mathbf{2}$ & Briket perekat tapioka 15\% & T2 \\
\hline $\mathbf{3}$ & Briket perekat tapioka 20\% & T3 \\
\hline $\mathbf{4}$ & Briket perekat tapioka 25\% & T4 \\
\hline $\mathbf{5}$ & Briket perekat jagung 10\% & J1 \\
\hline $\mathbf{6}$ & Briket perekat jagung 15\% & J2 \\
\hline $\mathbf{7}$ & Briket perekat jagung 20\% & J3 \\
\hline $\mathbf{8}$ & Briket perekat jagung 25\% & J4 \\
\hline
\end{tabular}

\section{B. Karakteristik Briket}

Briket yang baik adalah briket yang memenuhi standar SNI 01-6235-2000 (Badan Standarisasi Nasional, 2000).

1. Kadar Air

Kadar air menunjukkan jumlah kandungan air yang ada pada briket. Air pada briket bisa berasal dari bahan-bahan penyusunnya yaitu dari arang, dari tepung perekatnya dan pelarut untuk membuat perekatnya. Semakin tinggi kadar air maka briket akan semakin sulit dibakar. Diperoleh data sebagaimana tersaji pada grafik berikut.

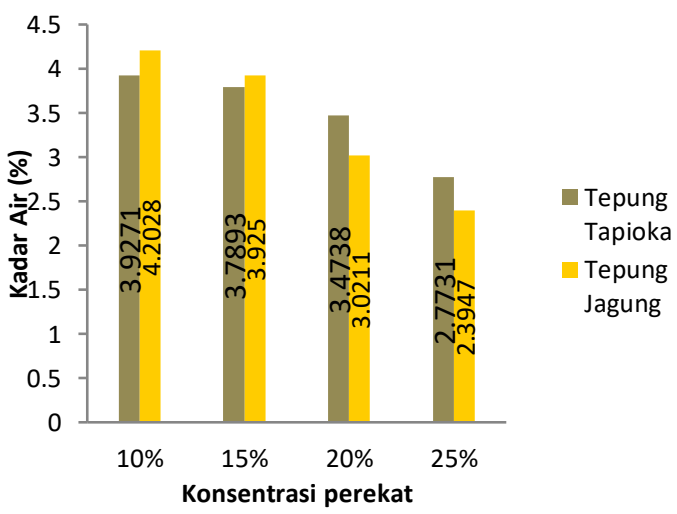

Gambar 1. Data Kadar Air Briket

Pada Gambar 1 bisa dilihat bahwa briket dengan perekat dari tepung tapioka memiliki kadar air dari 2,7\% hingga 3,9\% yang dimana memenuhi persyaratan SNI 1-6235-2000 yaitu di bawah 8\%. Begitu 
pula pada briket dengan perekat tepung jagung ini, dilihat dari Gambar 1 kadar airnya yaitu dari $2,3 \%$ hingga $4,0 \%$ dan ini pun memenuhi persyaratan SNI 1-62352000.

Briket dengan kadar air terendah adalah briket yang perekatnya berkonsentrasi $25 \%$ tepung tapioka dan tepung jagung, sedangkan paling tinggi adalah pada konsentrasi $10 \%$.

\section{Kadar Abu}

Kadar abu pada briket menunjukkan banyaknya sisa pembakaran briket. Semakin tinggi kadar abu pada sebuah briket menandakan briket yang kualitasnya rendah karena menyisakan sisa pembakaran yang tinggi juga. Berdasarkan penelitian di atas, diperoleh data sebagaimana tersaji pada Gambar 2.

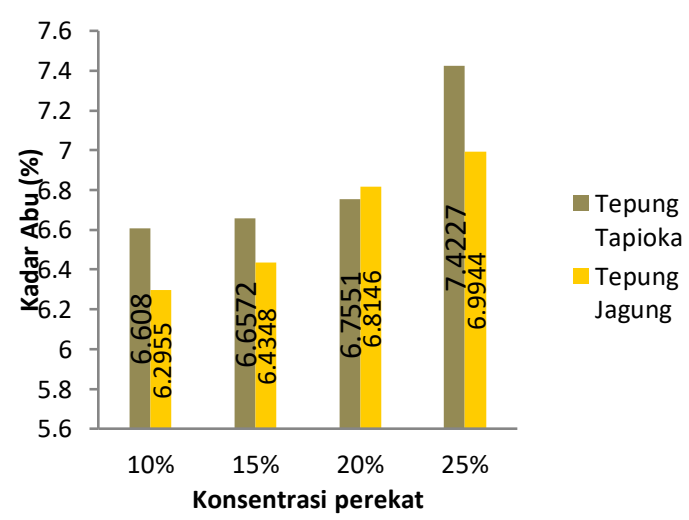

Gambar 2. Data Kadar Abu

Pada Gambar 2 bisa dilihat bahwa konsentrasi perekat berpengaruh pada kadar abu briket. Pada briket dengan perekat tepung tapioka memiliki kadar abu dari $6,6 \%$ hingga $7,4 \%$ yang dimana memenuhi persyaratan SNI 1-6235-2000 yaitu kadar abu pada briket maksimal $8 \%$. Begitu pula pada briket dengan perekat tepung jagung yang kadar airnya dari $6,2 \%$ hingga $6,9 \%$ dan memenuhi persyaratan SNI 1-6235-2000.

Briket dengan kadar abu terendah ada pada briket dengan perekat tepung tapioka dan tepung jagung berkonsentrasi paling rendah, yaitu pada konsentrasi $10 \%$ dan yang paling tinggi ada pada konsentrasi $25 \%$. Hal ini bisa terjadi karena tepung yang digunakan pada perekat berkontribusi dalam kadar abunya, semakin tingi konsentrasi perekat yang dibuat, maka semakin banyak juga tepung yang ditambahkan saat pembuatan perekat.

\section{Kadar Zat Menguap}

Kadar zat menguap pada pengujian kualitas briket ini menunjukkan jumlah zat yang dapat menguap pada briket pada suhu $900{ }^{\circ} \mathrm{C}$. Semakin tinggi kadar zat menguap pada briket ini berarti semakin banyak asap yang dihasilkan oleh briket saat pembakaran. Berdasarkan penelitian di atas, diperoleh data sebagaimana tersaji pada grafik berikut.

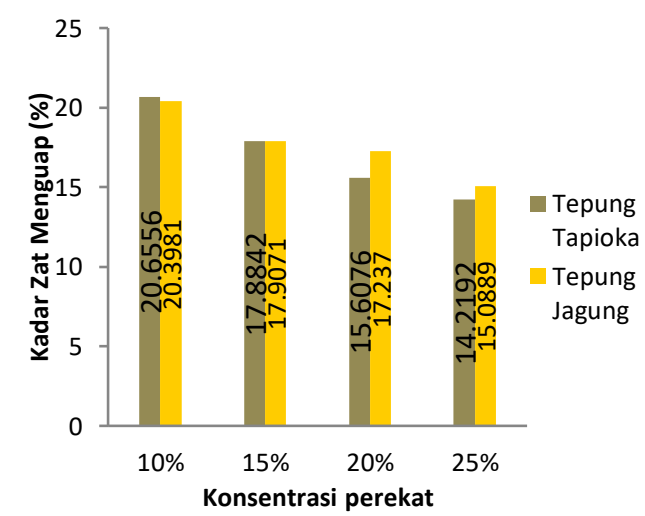

Gambar 3. Data Kadar Zat Menguap

Pada Gambar 3 dapat dilihat bahwa konsentrasi dan jenis tepung pada perekat mempengaruhi jumlah total zat menguap pada briket. Pada briket dengan perekat tepung tapioka memiliki kadar zat menguap dari $14 \%$ hingga 20\%. Dari variasi konsentrasi perekat dari tepung tapioka di atas, maka briket yang memenuhi persyaratan adalah pada konsentrasi 25\% karena pada SNI 1-62352000 maksimal kadar zat menguapnya adalah $15 \%$.

Sedangkan pada briket dengan perekat tepung jagung, memiliki kadar zat menguap dari $15 \%$ lebih hingga 20\%. Dari variasi konsentrasi di atas tidak ada yang memenuhi persyaratan karena pada 
konsentrasi $25 \%$ hasil kadar zat menguapnya di atas $15 \%$ atau $15,09 \%$ yang dimana telah disebutkan di atas bahwa menurut SNI 1-6235-2000 adalah maksimal $15 \%$.

\section{Kadar Karbon Terikat}

Kadar karbon terikat adalah salah satu pengujian kualitas briket yang dimana semakin tinggi kadar karbon terikat maka semakin baik kualitas briket yang dihasilkan karena kadar karbon terikat yang tinggi menandakan briket yang minim asap. Berdasarkan pengujian di atas, diperoleh data sebagaimana tersaji pada Gambar 4.

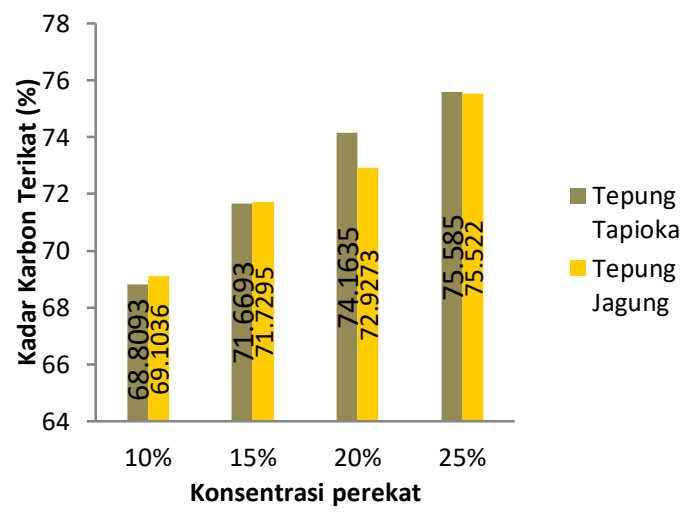

\section{Gambar 4. Data Kadar Karbon Terikat}

Dapat dilihat dari Gambar 5, bahwa briket dengan perekat dari tepung tapioka memiliki kadar karbon terikat dari $68 \%$ hingga $75 \%$ sedangkan pada briket dengan perekat dari tepung jagung memiliki kadar karbon terikat dari $69 \%$ hingga $75 \%$. SNI 1-6235-2000 tidak mensyaratkan kriteria kadar karbon terikat akan tetapi di negara lain menurut Budi dan Lilih (2017) briket yang berkualitas baik yaitu briket yang memiliki kadar karbon terikat $60 \%-80 \%$ oleh Japanese Agricultural Standard (JAS).

Penambahan perekat dengan konsentrasi berbeda mempengaruhi kadar karbon terikat pada briket. Semakin tinggi kadar air maka karbon terikatnya akan kecil, karena lebih banyak zat menguap. Begitu pula kaitannya dengan kadar zat menguap, semakin tinggi kadar zat menguap pada briket berarti semakin rendah jumlah karbon terikat pada briket.

\section{SIMPULAN}

Setelah melakukan penelitian serta pengujian kualitas seperti di atas, maka kami tarik beberapa kesimpulan : (1) Briket berbahan dasar arang kulit mahoni yang dibuat memenuhi persyaratan SNI 16235-2000 yaitu dengan jenis dan konsentrasi tertentu. (2) Kulit buah mahoni kering dapat diarangkan dengan pengarangan tanpa udara sehingga sangat bisa untuk dijadikan bahan baku briket. Akan tetapi kesulitan yang akan dihadapi adalah jumlah biomassa yang jumlahnya tidak begitu banyak, karena pohon mahoni sendiri merupakan pohon peneduh jalan. (3) Jenis tepung yang tepat untuk dijadikan perekat untuk briket berbahan dasar arang kulit buah mahoni ini adalah tepung tapioka atau tepung singkong dengan konsentrasi tepung dalam perekat sebesar 25\%. (4) Briket dari arang kulit buah mahoni dapat dijadikan bahan bakar alternatif.

\section{DAFTAR PUSTAKA}

[1] Badan Standarisasi Nasional. (2000). Wood Charcoal Briquette, SNI 01-6235-2000. Jakarta.

[2] Indrawijaya, B. (2019). Briket Bahan Bakar dari Ampas Teh dengan Perekat Lem Kanji. Jurnal Ilmiah Teknik Kimia., 3(1) : 23-28.

[3] Iswanto. (2016). Analisis Keragaman Genetik Jenis Mahoni (Swietenia Mahagoni (L) Jacq) Pada Berbagai Sumber Benih Di Sulawesi Selatan. Skripsi. Fakultas Kehutanan Universitas Hasanuddin, Makassar, Sulawesi Tengah.

[4] Kementrian Kehutanan, B. (2011). Dikutip pada 25 September 2017, dari http://www.bpdassolo.net/index.php/tan aman-kayu-kayuan/tanaman-mahoni. 
[5] Noldi, N. (2009). Uji Komposisi Bahan Pembuat Briket Biorang Tempurung Kelapa dan Serbuk Kayu Terhadap Mutu yang Dihasilkan. Skripsi. Fakultas Pertanian Universitas Sumatera Utara, Medan, Sumatera Utara.

[6] Salamah, S. (2008). Pembuatan Karbon Aktif Dari Kulit Buah Mahoni Dengan Perlakuan Perendaman Dalam Larutan $\mathrm{KOH}$. Prosiding Seminar Nasional Teknoin Bidang Teknik Kimia dan Tekstil.

[7] Samsi, A. S. (2000). Analisis Keragaman Genetik Pada Tanaman Mahoni Daun Besar (Swietenia Macrophylla King) Di Kebun Benih Parung Panjang. Skripsi. Fakultas Kehutanan Institut Pertanian Bogor, Bogor, Jawa Barat.

[8] Seran, J. B. (1990). Bioarang Untuk Memasak, Edisi 2. Liberti. Yogyakarta, DIY.
[9] Sinurat, E. (2011). Studi Pemanfaatan Briket Kulit Jambu Mente Dan Tongkol Jagung Sebagai Bahan Bakar Alternatif. Skripsi. Fakultas Teknik Universitas Hasanuddin, Makassar, Sulawesi Selatan.

[10] SNI $3451: 2011$. Tapioka.

[11] Soeyanto, T. (1982). Cara Membuat Sampah Jadi Arang Dan Kompos. Yudhistira. Jakarta.

[12] Sudiro \& Sigit S. (2014). Pengaruh Komposisi Dan Ukuran Serbuk Briket Yang Terbuat Dari Batubara Dan Jerami Padi Terhadap Karakteristik Pembakaran. Skripsi. Politeknik Indonusa Surakarta, Surakarta, Jawa Tengah. 